\title{
Change at the Top: Succession in the Chinese Communist Party
}

\author{
Brendan Forde
}

\section{Abstract}

Faced with the challenge of leadership change, the Chinese Communist Party (CCP) has sought and established an institutionalised process of succession. The People's Republic of China (PRC) is an authoritarian regime; leadership change presents specific problems in the management of succession at the elite levels of the political process. The two line leadership succession mechanism is the means by which the CCP has attempted to provide certainty and stability in leadership succession. It is a normative institutionalised process, regulating elite behaviour and ensuring certainty in succession. The Party has learnt from substantial past challenges to evolve into an organisation which recognises the need to prevent social upheaval. The CCP has evolved from an organisation with leadership based on extra-institution and charismatic leadership, to an organisation which engages in planned succession and orderly processes in elite politics. The mechanism enables observers (both domestic and international) to know in advance who next will lead China. The mechanism also sets fixed terms for the incumbent leadership, providing the system with clearly signposted periods indicating when the succession process is to begin. The cult of the charismatic leader able to select their successors has given way to a stable, institutionalised and predictable process. The two line leadership succession mechanism is an indicator of the changes taking place in Chinese politics today.

\section{Introduction}

The year 2012 will be an important year for China. For only the second time in the history of the Chinese Communist Party (CCP) and the People's Republic of China (PRC) a semi-institutionalised whole scale renewal of political leadership will begin. The present Party-state leadership will voluntarily step aside and a new generation of leaders will take office. President $\mathrm{Hu}$ Jintao will retire from all positions and Vice-President Xi Jinping will assume office as the new leader of China. Over a period of twelve months the incumbent generation will divest itself of all formal offices while the successor generation will assume control 
over the Party-state. This article examines the institutional procedures which have been developed by the CCP to facilitate and manage a stable and successful transition of leadership. With the rise of the PRC as a major power it is more important than ever to better understand the key institutions which contribute to the stable governance of the nation.

Since taking power in 1949 the CCP has evolved from a revolutionary movement to a party of government and administration. ${ }^{1}$ The leaders of the CCP today are markedly different from their predecessors in a few crucial respects. Mao Zedong and Deng Xiaoping wielded significant extra-institutional power and influence, the source of their authority and political legitimacy stemming largely from their own charismatic presence. ${ }^{2}$ Jiang Zemin and Hu Jintao, on the other hand have not enjoyed the same level of charisma as Mao or Deng. As David Bachman writes of Mao

In short, Mao built the system that rules China today... Through both spontaneous and manufactured means, Mao carried a charismatic aura about his person. His will to power was unstoppable and he was absolutely ruthless in securing his unconstrained power and freedom of action. $^{3}$

Mao's successors, while still powerful, could not command the same level of charismatic authority:

1 Samuel P. Huntington has written about three broad stages through which a revolutionary party transforms into an established ruling party: "In the initial transformation phase, the party destroys the traditional sources of authority. In the second phase, it consolidates its authority as an organisation against the charismatic appeals of the founding leader. In the third, adaptive phase, the party deals with legal-rational challenges to its authority, which are, in large part, the product of its earlier successes". Samuel P. Huntington, "Social and Institutional Dynamics of One-Party Systems" in Samuel P. Huntington and Clement H. Moore (eds.), Authoritarian Politics in Modern Society: The Dynamics of Established One-Party Systems, (New York: Basic Books, 1970), pp., 32-33.

2 The term charisma is used here in the Weberian sense, that is, applied "... to a certain quality of an individual personality by virtue of which he is set apart from ordinary men and treated as endowed with supernatural, superhuman, or at least specifically exceptional powers or qualities". The critical feature of this source of power is: "Charismatic authority is thus specifically outside the realm of everyday routine and the profane sphere. In this respect it is sharply opposed both to rational, and particularly bureaucratic, authority and to traditional authority whether in its patriarchal, patrimonial, or any other form... Bureaucratic authority is specifically rational in the sense of being bound to intellectually analysable rules; while charismatic authority is specifically irrational in the sense of being foreign to all rules." This theory is essentially a sociological interpretation of charisma and emphasises both the "exceptional characteristics of the individual invested with charisma and the social conditions fostering the emergence and recognition of charismatic leaders". Max Weber, The Theory of Social and Economic Organisation, (New York: Oxford University Press, 1947). The charismatic authority of Mao and Deng was significantly different- Mao's charisma was clearly derived from his role in the foundation of the CCP and PRC. As the leader of the revolution he could rely upon his charismatic authority to circumvent and supersede the authority and institutions of the state. Deng's charisma was less discernibly strong but it was significant enough for him to wield significant extrainstitutional authority during his time as paramount leader. The political legitimacy of both Mao and Deng came largely from their charisma.

3 David Bachman, "The Limits on Leadership in China", Asian Survey, Vol. 32, No. 11, (Nov. 1992), p. 1046. 
In contrast, Deng Xiaoping's political resources and background suggest that he has had significantly less power than Mao. Deng played an important role in the communist movement prior to 1949 , but he was not one of the top ten or so leaders of the CCP when it came to power. ${ }^{4}$

While in the past the CCP was dominated by charismatic personalities who were able to select their own successors, the leaders of today cannot rely on that same ability. The Party now governs through collective leadership. Past and current leaders are no longer able to anoint a chosen successor for the next generation. This has been achieved through semi-institutionalised processes. Matters of succession without regulation will typically trigger a power struggle between the different figures vying for the senior position. This is particularly the case in the context of a succession taking place free from a transition.

The two line leadership succession mechanism is the subject of this paper. As the means by which the CCP engages and manages leadership change, it is not only an important exemplar of the institutional trend in Chinese politics but also an important indicator of the conscious attempts made by the CCP leadership to ensure the continuing viability of the Party as the dominant political organisation in Chinese society. It is the strongest and most coherent attempt made by an authoritarian regime to institutionalise not only the transition and succession of leadership but also the exercise of power. The mechanism has created new rules for political exchanges; it has restrained the contest for power among the individuals in the highest echelons of the CCP. Taking place over the course of twelve months, the mechanism ensures the stable and binding transition of leadership. Each senior leader of the PRC occupies three key offices: President of the PRC, General Secretary of the CCP and Chairman of the Central Military Commission. Through these three offices the leader is the head of state, Party and the military. This authority is not limitless; the President is constitutionally bound to serve for two five year terms only and all senior Party leaders are compelled to retire after they turn seventy years old. Clearly identifying and designating a successor is a pressing task for the CCP. A successor will come from among the political elite and will be identified and elevated at the beginning of the incumbent's second term. The successor will be designated as Vice President of the PRC, Vice Chairman of the CMC, First Secretary of the CCP Secretariat and President of the CCP Central Party School. The appointment of the successor to these key posts has three purposes: firstly, by making him ${ }^{5}$ the deputy to the incumbent the relationship between the two is sufficiently regulated and demarcated. Secondly, the successor is able to gain

4 Ibid., p.1049.

5 The masculine personal pronouns "him" and "he" are used as elite politics in the PRC remains dominated by patriarchy. A few women have risen to prominent positions within the regime, but none of them were considered as serious contenders to become senior leader (despite their clear abilities). 
key experience and legitimacy in the highest levels of government. Thirdly, by publically identifying and elevating a successor the Party sends a message to the other elite players that he (the successor) has been selected and political conflict on this matter must cease. ${ }^{6}$ The mechanism itself is centred on the nine member Politburo Standing Committee (PBSC). ${ }^{7}$ The members of the PBSC are the nine most important individuals in the Chinese state. The senior officers of the government and Party simultaneously hold positions on the PBSC; indeed, the source of their authority comes largely from their membership of the PBSC .

\section{Institutions - The Locus of Succession}

The two line leadership succession mechanism is a political institution. Equally institutionalised succession and transition processes in the CCP are the product of past and present evolution in norms and practice. While an institution can be a concrete organisation it can also constitute rules, norms and other more ephemeral aspects of political activity. Institutions are frequently invoked in political science, being applied to formal bodies like parliaments and amorphous entities like social clans, as well as other components of the socio-political universe also being described as institutions. ${ }^{9}$ The term institution applies to a diverse grouping of entities but the utility of an institution can be found not in what an institution is but in what it does. A good institution is an effective institution. ${ }^{10}$ They can range from a statutory provision to a collection of

6 The origins of two lines of leadership within the CCP can be traced back to the 1950's when Mao Zedong distinguished between his own position and that of the General Secretary: "The Politburo is the 'court of political planning,' and authority is concentrated in the Politburo Standing Committee and the Secretariat. As chairman, I am the commander; as general secretary, Deng Xiaoping is the deputy commander". "Deng Xiaoping chengwei dang de di'erdai lingdao hexin" [Deng Xiaoping's designation as the party leaderships second generation core] in Guo Dehong, Zhang Zhanbin and Zhang Shujun (eds.). Dang he guojia zhongda juice de licheng [The course of important policy decisions in our party and county]. Vol. 8. (Beijing: Hongqi chubanshe, 1997). pp. 365-366. This same quote appears in Chen Mingxian, Cui Yanming, “Mao Zedong du Deng Xiaoping de ruogan lunshu" ["Mao Zedong's certain discussions on Deng Xiaoping"], Zhonggong dangshi ziliao [Materials on Party history] No. 58, (June 1996).

7 The PBSC is, according to Nathan and Gilley: “On paper just a Party organ, the PBSC makes all important decisions on national policy concerning the economy, foreign affairs, defence, science and technology, welfare, and culture- policy in every sphere of life. It can deal with any issue it wants to. No other organ of the Party or government has the power to contradict its decisions." Andrew J. Nathan and Bruce Gilley (eds.), China's New Rulers: The Secret Files, (London: Granata, 2002), p. 8. The actual size of the Politburo Standing Committee has expanded over the past two decades. But while its size has changed the PBSC's only constant is that the membership is made up of an odd number of members to guard against the possibility of a deadlocked vote. The nine members of the PBSC are selected from among the twenty members of the Politburo who are in turn elected by the three hundred and seventy members of the Central Committee. Ibid, pp. 7-8.

8 Ibid. p. 9.

9 B. Guy Peters, Institutional Theory in Political Science: The 'New Institutionalism', (London: Continuum, 2005), P. 29. Peters argues that: "An institution is anything from a formal structure to very amorphous entities". Ibid., p. 29.

10 Ibid., p. 125. 
normative customs and unwritten conventions. ${ }^{11}$ Institutions are ephemeral in that they constitute interests and cause things to happen, even though they are socially constructed and not material in a physical sense. ${ }^{12}$

The analysis of institutions, and institutionalism, is as Johan P. Olsen asserts, a specific way of interpreting political institutions. ${ }^{13}$ As Ronald L. Jepperson has argued, institutions provide a framework to explain the presence of authoritative rules and binding organisation. ${ }^{14}$ An institution, according to Olsen, can be conceived as an enduring collection of prescribed behavioural rules and organised practices, embedded in structures and processes. ${ }^{15}$ An institution is not necessarily a formal structure; it can be understood as a collection of norms, rules, understandings and routines. ${ }^{16}$ In turn, these interrelated rules and routines define appropriate political activity in terms of relations between roles and situations. ${ }^{17}$ There are competing accounts of the role of institutions. However, this paper agrees that:

Institutions are comprised of regulative, normative and culturalcognitive elements that, together with associated activities and resources, provide stability and meaning in social life. ${ }^{18}$

Institutions require a broader organisational context within which to operate and they arise due to historical and political events in each country. ${ }^{19}$ This is certainly the case with the two line leadership succession mechanism with the mechanism standing as an institution to the organisation of the $\mathrm{CCP}^{20}$ One of the

11 No sufficient all encompassing and conclusive definition of a political institution exists, as the term refers to an area of great diversity. As Schmidt writes: "Institutions may be real in the sense that they constitute interests and cause things to happen, even though they are socially constructed and thus not material in a 'put your hand or rest your eyes on it' sense". Vivien A. Schmidt, "Discursive Institutionalism: The Explanatory Power of Ideas and Discourse", Annual Review of Political Science, (2008), p. 318.

12 Ibid., p. 318.

13 Johan P. Olsen, Governing Through Institution Building: Institutional Theory and Recent Experiments in Democratic Organizations, (Oxford: Oxford University Press, 2010 ), p. 7.

14 Ronald L. Jepperson, "Institutions, Institutional Effects, and Institutionalism", Walter W. Powell and Paul J. Di Maggio (eds.), The New Institutionalism in Organisational Analysis, (Chicago: The University of Chicago Press, 1991), p. 143.

15 Olsen, op. cit, p. 36.

16 Peters, op. cit., p. 26.

17 Ibid. p. 29.

18 W. Richard Scott, Institutions and Organisations: Ideas and Interests, (Los Angeles: Sage, 2008), p. 48.

19 Marco Orrù, Nicole Woolsey Biggart, and Gary G. Hamilton, "Organisational Isomorphism in East Asia", Walter W. Powell and Paul J. DiMaggio (eds.), The New Institutionalism in Organizational Analysis, (Chicago: The University of Chicago Press, 1991), p. 366.

20 Defining a political party as an organisation and not an institution is not contested, although this is most likely due more to terminological ambiguity, than to more specific clauses. An example of this contestation comes from Peters : "Political parties are one of the dominant players in the political arena and like any organisations can be conceptualised as institutions. Many of them do have the persistence that one expects of an institution...". Peters, op. cit., p. 125. Persistence alone does not make an institution, and while political parties differ dramatically, the CCP is clearly a highly organised entity with strong institutional features. By this reckoning, the CCP is an organisation with institutional elements. Peters seems to agree with this definition: "Political parties may differ, however, in the degree of institutionalisation of their structures and 
most important elements of an institution is that it is a structural feature of the polity. ${ }^{21}$ The extension and expansion of the role of institutions is both a process and a property of organisational arrangements implying that an organisational identity has been established and accepted as legitimate. ${ }^{22}$ This involves clarity and agreement on rules governing behaviour including the allocation of formal authority. ${ }^{23}$ By providing a framework of rules, along with attendant formalisation of practice, uncertainty and conflict over roles are significantly diminished. ${ }^{24}$ An institution so conceived is a normative institution.

While normative institutions establish a framework within which to bind political behaviour, to categorise normative institutions as being exclusively a structure for constraint would be misleading. ${ }^{25}$ All institutions simultaneously empower and control participants, acting as vehicles for activity within certain constraints. ${ }^{26}$ Normative institutions can be understood in terms of "what is good or bad about what is" in light of "what one ought to do" ${ }^{27}$ This comes from the consensus which arises out of the rules of behaviour and the common justification and expectations which arise out of those rules. ${ }^{28}$ The utility of theories involving institutional constraints comes from the applicability and adaptability of outcomes across different cultures and societies. ${ }^{29}$

\section{Succession or Transition?}

The two line leadership succession mechanism is a semi-institutionalised process broadly conforming to the characteristics of a normative institution. Arranging succession which will maintain political stability in an authoritarian regime such as the PRC is difficult, as Myron Rush writes:

\footnotetext{
in the extent to which they attempt to utilise rules to control the behaviour of their members. At one extreme might be communist, fascist and other strongly ideological parties that attempt to mould the behaviour of their members through formalised rules as well as through ideologies that could internalise those controlling values". Ibid. p. 124.

21 Ibid., p. 18. Peters writes: "That structure may be formal (a legislature, an agency in the public bureaucracy or a legal framework) or it may be informal (a network of interacting organisations, or a set of shared norms). As such an institution transcends individuals to involve groups of individuals in some sort of patterned interactions that are predictable, based upon specified relationships among the actors". Ibid. p. 18.

22 Olsen, op. cit., p. 127.

23 Ibid., p. 127.

24 Ibid.

25 Jepperson, op. cit., p. 146.

26 Ibid. p. 146.

27 Schmidt, op. cit. p. 306

28 Olsen, op. ct., p. 127.

29 Andrew J. Nathan and Kellee S. Tsai, "Factionalism: A New Institutionalist Restatement", The China Journal No. 34, (Jul. 1995), p. 161
} 
Communist rulers, on the whole, have gone to remarkable lengths in efforts to arrange their succession. Usually they have been reluctant to call attention to these efforts, for they indicate the temporal limits of their own rule. ${ }^{30}$

The danger here lies in the lack of an institutionalised process to govern the succession. Without a clearly enunciated timeframe for the succession process and without clearly defined mechanisms which compel the incumbent to stand aside, a successor could instigate action to assume leadership, and the incumbent could become insecure expecting a leadership takeover. ${ }^{31}$ Such circumstances do not create effective and stable government. This non-institutionalised succession arrangement conforms to much of the succession experience of the PRC. ${ }^{32}$ The $\mathrm{CCP}$ has attempted to address this by creating a mechanism which both provides a clearly outlined process for succession while impelling the incumbent to retire.

Before proceeding it is important to define the precise characteristics of political succession and transition (the danger exists that the terms may be used interchangeably). Rush argues that:

Political succession is the transfer of sovereign power from a ruler or government to a successor. Such rotation is made inevitable by man's mortality, but it does not always wait on the death of leaders. Since changed circumstances cannot always be met by change in the leaders themselves, they may be required by the constitution or compelled by force to leave office during their own lifetime. ${ }^{33}$

Paul 't Hart and John Uhr place succession and transition in a more practical context than Rush when they describe transition as:

...change in the party or coalition that holds government. Transitions imply that multiple ministers or political appointees are rotating at the same time, and that all or many of the newcomers experience a shift from campaigning, waging opposition or holding non-political offices to running executive government... ${ }^{34}$

They hold that succession denotes:

30 Myron Rush, How Communist Party States Change their Rulers, (Ithaca: Cornell University Press, 1974).

31 Ibid.

32 The case of Mao Zedong and Lin Biao immediately springs to mind.

33 Myron Rush. Political Succession in the USSR. (New York: Columbia University Press, 1967). p. 1.

34 Paul 't Hart and John Uhr. "Power Transitions and Leadership Successions in Government" in Paul 't Hart and John Uhr (eds.). How Power Changes Hands: Transition and Succession in Government. (New York: Palgrave Macmillan, 2011). p. 2. 
...personnel changes in individual leadership positions within government (or political parties). The most dramatic succession of all is that between holders of the head of government position. ${ }^{35}$

The definition of succession can be applied to the analysis of leadership succession in elite Chinese politics; it is indeed a definition which has universal application. However, the definition of transition requires modification to render it more useful to this study. While succession refers to a change within the leadership of the governing organisation, the term transition denotes the change of the governing organisation. This particular categorisation is inapplicable to the context of the PRC as a change in the governing organisation would lead to displacement of the CCP as the ruling Party and thus the fall of the regime. When expanded to encompass changes among the broader political groupings within the CCP the definition of transition becomes applicable to the study of leadership change in the PRC. Leadership transitions in the PRC occur on an intra-Party basis, that is, while the governing party may stay the same the generation ${ }^{36}$ of leaders holding office changes. The concept of political generations, in this context, is peculiar to the CCP. Five generations have led the PRC, each with a senior leader. While Mao Zedong was the senior leader of the First Generation, Xi Jinping is the senior leader of the Fifth. ${ }^{37}$ The relationship between succession and transition requires clarification. It would be erroneous to assign a causal relationship between transitions and successions. As $\mathrm{t}^{\prime}$ Hart and Uhr write: "Each transition entails a number of successions, but not every succession necessarily comes about as part of a transition." ${ }^{\prime 38}$ Extra-transitional successions are generally unplanned and arise from the premature death or

\footnotetext{
35 Ibid. p. 5.

36 The CCP divides its members into different generational categories based upon when the individual became members and their age. This particular definition of members was first identified by A. Doak Barnett. A. Doak Barnett, Cadres, Bureaucracy and Political Power in Communist China, (New York: Columbia University Press, 1967).

37 The concept of political generations in the Chinese context requires further specification. As Cheng $\mathrm{Li}$ writes: "The term "political generations" is frequently used but not carefully defined". Cheng Li, "Jiang Zemin's Successors: The Rise of the Fourth Generation of Leaders in the PRC", The China Quarterly, No. 161 (Mar., 2000), p. 4. A careful definition of the term comes from Michael Yahuda who has explored this very subject: "The term "political generation" should not be equated with the concept of biological generation as between father and son... It is the contention here that the differences in historical experiences and the reactions to those experiences as between different age groups are of greater significance than what might be called purely biological considerations". Michael Yahuda, "Political Generations in China", The China Quarterly, No. 8, (Dec., 1978), p. 795. Both Li and Yahuda seem to draw from the work of Karl Mannheim on political generations. Mannheim distinguishes between a generation as demographic category and as an experiential category. Mannheim also argues that generations cannot be considered as monolithic entities. Based on a variety of factors, each generation holds a diversity of views. Karl Mannheim, Essays on Sociology of Knowledge, (London: Routledge and Keegan, 1952). Li further refines the definition when he writes: "The term "political generations" that many sinologists have used in their studies may be more accurately identified as "political elite generations"'”. Li, “Jiang Zemin's Successors", op. cit. p. 5. This is an important distinction which any conceptualisation of organised leadership change in the PRC must remain cognisant of. This study deals with the political affairs of the elite and the means by which the elite seek to protect and further their monopoly over power.
}

38 t' Hart and Uhr, op. cit. 
removal of a leader. Such unplanned successions can be a source of instability for authoritarian regimes like the PRC. By creating clear distinctions between the different generations and strongly compelling the incumbent leaders to step aside, the mechanism avoids a situation whereby senior figures from previous generations can continue to exercise disproportionate influence from retirement.

\section{From Ambiguity to Certainty}

The exercise of disproportionate power from retirement by a few key figures informed and impelled the development of processes to initiate and manage leadership change. The context for the emergence of such processes can be found during the period immediately after the end of the Cultural Revolution. ${ }^{39}$ Hua Guofeng, Mao's anointed heir and successor, was removed from power by Deng Xiaoping and his supporters. After the end of the Cultural Revolution in 1976 many members of the elite who had been purged or removed from power during the course of the Cultural Revolution, including Deng Xiaoping, were restored to positions of authority. Since the foundation of the regime, the PRC and CCP had only one leader, Mao Zedong, and he left office only through death. While Hua could not command a level of support and authority commensurate with Mao, his status as the chosen successor vested him with some authority and legitimacy. Hua had been elevated to power during the closing days of the Cultural Revolution replacing Zhou Enlai as the Premier of the PRC after the latter's death in 1976. As Vice Chairman he was Mao's successor. Much emphasis was placed on his status as Mao's personally anointed successor, as evidenced by the note which Mao wrote to Hua in his dying days. ${ }^{40}$ Hua's status as Mao's successor proved to be both a benefit and a political liability. The recently restored members of the political elite were reluctant to serve under a figure representative of the circumstances which had removed them from power in the first place. To counteract the various limitations to action the restored elite chose a different path to challenge Hua. Rather than challenge him openly, Hua was gradually divested of his offices, ${ }^{41}$ while the position of Chairman was totally abolished. ${ }^{42}$ Deng had mobilised the restored elite and had risen to the

39 The Cultural Revolution, initiated by Mao in 1966 (and ended with his death in 1976), displaced many members of the pre-1966 elite and destabilised the entire country.

40 The most famous quote from the hand written note reads: “... with you in charge, I am at ease". Reprinted in John Gardner, Chinese Politics and the Succession to Mao, (London: The Macmillan Press, 1982).

41 Hua held several offices simultaneously: Chairman of the CCP, Chairman of the CCP Central Military Commission, Premier of the PRC, Minister of Public Security and First Secretary of Hunan Province. David S. Goodman, "China: The Politics of Succession", The World Today No. 4, (April, 1977).

42 Lowell Dittmer, "Patterns of Elite Strife and Succession in Chinese Politics", The China Quarterly, No. 123 (Sep., 1990). 
position of the dominant figure in the Chinese party-state. ${ }^{43}$ However, Deng did not assume a senior role in the Party or government. He became Chairman of the CMC and for a time served as a Vice Premier. Despite not serving as the formal head of the party-state, Deng enjoyed disproportionate influence over the political process and became the acknowledged paramount. ${ }^{44}$ Without a formal, unitary executive office to clearly mark the leader of the party-state, Deng and the other members of the elite were free to influence and control the political process. Those figures who did serve as the formal leaders of parts of the partystate (such as General Secretary Hu Yaobang, and his successor Zhao Ziyang) found that they were functionally answerable to a group of retired leaders. As the members of the restored elite were of an advanced age, China had become, in the words of Parris H. Chang, a "gerontocracy". ${ }^{45}$

While the dissolution of the office of Chairman was conceived as an attempt to achieve, as Kenneth Lieberthal has described it, "functional differentiation" between the offices of Party and state, the real effect was "functional ambiguity". ${ }^{46}$ With some figures being able to dictate from retirement, it was not clear who was really in charge. This ambiguity most directly affected the General Secretary Hu Yaobang, Deng's anointed successor. Hu found his actions increasingly constrained by the interference of the retired leaders, including Deng. Coupled with this was the destabilising factionalism which was gripping the Party, with many of the retired figures standing opposed to $\mathrm{Hu}$ and his reform programme. ${ }^{47} \mathrm{Hu}$ reportedly confronted Deng and complained that he could not execute his position while Deng remained involved in politics: "Be an

\footnotetext{
43 Fewsmith writes that the most important factor assisting Deng was “... the revolutionary legitimacy Deng possessed by virtue of his long participation in and major contributions to the victory of CCP and the administration of the PRC prior to the Cultural Revolution. Nevertheless, despite such revolutionary legitimacy, Deng did not challenge Hua Guofeng in intra-party meetings and then articulate an agenda but rather the other way around, underscoring the importance of issues in legitimating leadership." Joseph Fewsmith. Elite Politics in Contemporary China. (Armonk NY: ME Sharpe, 2001).

44 Dittmer, op cit. p. 408

45 Chang writes: “Thus, under Deng, a leadership system of gerontocracy emerged in which the elders ultimately exercised greater influence than the younger leaders. Long Marchers who had seized power in 1949, and who had been purged in Mao's Cultural Revolution and later politically rehabilitated, were still ultimately running the country in the 1980s. The Chinese leadership system remained highly personalised and not institutionalised, and the power of a leader largely depended on his past, personal qualities and guanxi (networks of personal connections) and much less on his official position. This was why the general secretary of the Party and the premier, who were theoretically the ranking Party and government officials, had to take orders from the old guard." Parris H. Chang. "Changing of the Guard". The China Journal. No. 45 (January, 2001).

46 Kenneth Lieberthal, "China's Political Reforms: A Net Assessment", Annals of the American Academy of Political and Social Sciences, Vol. 476, China in Transition (Nov., 1984).

47 The factions were broadly organised along the lines of differing attitudes to reform. The reformists (including $\mathrm{Hu}$ Yaobang and Zhao Ziyang) wanted to extend the scope of economic reform, while the conservatives (including Chen Yun) wanted to limit the scope. These two groupings were sharply divided by age, with the retired leaders making up the leadership of the conservative faction. Deng's position existed between these camps, pushing and shielding the reformists while a peer of the conservatives, by virtue of his age.
} 
example. I cannot work efficiently while you are still in power." ${ }^{48}$ While Hu was formally the head of the CCP, in truth: “...the party general secretary was not the real leader but was more of a clerk who had to please several elderly bosses; nor did he have secure tenure....". ${ }^{49}$ Hu's plea to Deng to retire contributed to his eventual removal in 1987. Hu was replaced by Premier Zhao Ziyang. Perhaps Deng recognised the mistakes of his relationship with $\mathrm{Hu}$, as he vested Zhao with greater authority. Two lines of leadership between Deng and Zhao on economic planning and policy making were already clear. In 1986 Deng received a delegation from Yugoslavia and informed them that, with regards to economic policy making, that he set the direction of policy while Zhao carried it out in detail. ${ }^{50}$ Two lines also became apparent in military affairs, with Zhao being appointed as a senior Vice Chairman of the CMC. ${ }^{51}$ The fundamental role of Deng as an extra-institutional leader remained unchanged. During Soviet leader Mikhail Gorbachev's visit to China in 1989 Zhao informed him in a meeting that while Deng had formally retired from all Party offices (he was still Chairman of the $\mathrm{CMC}$ ), his wisdom and experience were invaluable resources for the $\mathrm{CCP}$ and on all important questions and decisions. Deng would remain firmly in charge. ${ }^{52}$ This comment (which aggrieved relations between Zhao and Deng) confirmed that Deng continued to wield significant authority from retirement.

Along with the factional conflict among the elite, Chinese society was changing significantly. In the midst of the expansion of economic reforms, protests in favour of the extension of political reforms increased. These protests were driven by university students and culminated in the occupation of Tiananmen Square in early 1989. On the evening on May 27 eight leaders of the restored elite gathered at Deng Xiaoping's residence in Beijing..$^{53}$ Apart from Deng himself,

48 Pang Pang, The Death of Hu Yaobang, (Honolulu: University of Hawaii, 1989).

49 Chang, op. cit.

50 "Deng Xiaoping he Zhao Ziyang de guanxi" ["The relationship between Deng Xiaoping and Zhao Ziyang"], Duwowei xinwen wang [DW Internet News], 08/01/2007.

51 Yan Kong writes: "The party CMC created after the 13th National Congress dropped Yu Qiuli, Zhang Aiping and Yang Dezhi [senior generals]. In their place, the commission recruited party chief Zhao Ziyang as the first vice-chairman... The state CMC formed at the 7th National People's Congress in 1988 introduced the newly appointed chiefs of the three general headquarters...The first vice-chairman's seat was specifically created for Zhao Ziyang, apparently to pave the way for a smooth transfer of power from Deng to Zhao, the latter not have [sic.] any personal connections... with the military". Yan Kong, "Institutional Developments in China's Central Military Commission", Jane's Intelligence Review, Vol. 5, No. 4 (1993).

52 Andrew J. Nathan and Perry Link (eds.), The Tiananmen Papers, (London: Little Brown and Company, 2001).

53 Almost to make a point about his role as an extra-institutional figure Deng refused to live in the leadership compound in the Zhongnanhai. As Fewsmith writes: "Outside observers have long referred to Deng Xiaoping as China's 'paramount leader', but Zhao's memoir makes clear precisely how preeminent he was. Deng worked at home and summoned others to meet with him there [these were official meetings, and minutes were taken]. In the whole volume [of Zhao's memoirs], there is only one instance in which Deng travelled to Zhongnanhai, and that was to preside over a formal Politburo meeting. Deng may have been subject to the pressure of other senior leaders, but there is not an obvious instance of Deng yielding against his own preference to the will of others. Deng may have been influenced by others, but he made up his own mind". Joseph Fewmsith, "What Zhao Ziyang Tells Us about Elite Politics in the 1980's", China Leadership Monitor No. 30, (Fall, 2009), p. 3. 
Chen Yun, Li Xiannian, Peng Zhen, Deng Yingchao, Yang Shangkun, Wang Zhen and Bo Yibo attended. The assembled group constituted the core of the second generation of leaders and the leadership of the conservative faction. Absent from this meeting was Premier Li Peng, who had been a major factional opponent of Zhao and a vocal critic of his conciliatory attitude to the protestors. With Li's absence no formal leader of the Party or state was in attendance. Although an informal gathering, the consequences of the meeting were significant. ${ }^{54}$ During the meeting Deng announced that Shanghai Party Secretary Jiang Zemin would be proposed to be elevated to replace Zhao Ziyang as General Secretary (who had already been removed). The role of Deng is clear: no one opposed his proposal to elevate Jiang. This decision was made outside of formal party processes.

The Tiananmen crisis damaged the CCP's legitimacy and credibility. The lessons of the period were well learned by Deng and the CCP. Deng resigned as Chairman of the CMC, elevating Jiang to the position. Jiang added to his positions the Presidency of the PRC in 1992. Elevating Jiang to the Presidency was an interesting move. The President of the PRC is an office endowed with significant legitimacy, both at home and abroad even though it is a largely ceremonial post. Jiang could legitimately command authority over the Party, state and military. With the designation of a single leadership figure the ambiguity of differentiated authority was removed. After 1992 Deng intervened less frequently in the political process. Apart from addressing the matters of functional ambiguity arising from the dissolution of the office of Chairman, the CCP also endeavoured to maintain a stable atmosphere among the elite, with an emphasis on struggle and conflict at times of transition. As Fewsmith writes:

It is now more difficult to engage in a winner-take-all contest for political power in a post-Tiananmen atmosphere in which the likely outcome is not that one side will win but that all will loose..$^{55}$

Eventually, Deng's generation of leaders gave way to Jiang's, but not through a planned transition. By the time of Deng's death in 1997 most of the members of the restored elite had died or were dying. ${ }^{56}$ Before his death, Deng had installed $\mathrm{Hu}$ Jintao as a successor to Jiang thus ensuring his own influence over events into the future:

\footnotetext{
54 The transcript of the meeting appears, verbatim, in The Tiananmen Papers. Nathan and Link, op. cit.

55 Joseph Fewsmith, "The New Shape of Elite Politics", The China Journal, No. 45 (Jan. 2001). Rod Wye adds: "A number of key lessons were taken to heart from this post-mortem examination [of Tiananmen]. Never again was leadership disunity or serious disagreement within the leadership to be permitted to go on public display and allow the leadership to be seen as anything but united and unanimous. Competition between leaders would have to take place behind closed doors. Public disunity within the leadership was seen as one of the crucial factors that encouraged and enabled the sense of chaos and political paralysis in 1989." Rod Wye. "China's Leadership Transition" in David Shambaugh (ed.). Charting China's Future: Domestic and International Challenges. ( New York: Routledge, 2011).

56 Fewsmith writes: "In the 1990's, the actuarial tables finally caught up with the revolutionary generation that had dominated politics for half a century". Fewsmith, "The New Shape of Elite Politics", op. cit., p. 83.
} 
Deng Xiaoping not only designated Jiang Zemin as his successor but was also able to name $\mathrm{Hu}$ Jintao as Jiang's successor. But as the political system moves into the future there will be no ghost of the past deciding the leadership; it will have to be decided among a group of elites of relatively equal standing. ${ }^{57}$

The influence of Deng's "ghost" will not be felt in a substantive manner during the next transition of leadership. When examining the role of Deng in this process, it would be erroneous to conclude that it was his intention to construct an institutionalised mechanism to ensure leadership transition and succession. Deng was more concerned with who held the office rather than how long they held the office. ${ }^{58}$

Jiang's tenure came to an end in 2002 at the $16^{\text {th }}$ CCP Party Congress. Despite the speculation that he would retain power, Jiang and his fellow leaders resigned their political offices. This was unprecedented in the history of the PRC: never before had a leadership transition occurred while the incumbents were alive and in sound health. ${ }^{59} \mathrm{Hu}$ Jintao had been designated as the successor to Jiang, and had assumed the offices of Vice President of the PRC, Vice Chairman of the CMC, First Secretary of the Party Secretary and President of the CCP Central Party School. Hu was clearly designated as the successor to Jiang. Two lines of leadership became apparent between Jiang and $\mathrm{Hu}$, particularly in military policy. ${ }^{60}$ Establishing two lines of leadership is crucial to providing experience and legitimacy to the successors. This particular aspect of the succession has been recognised as important and essential by the CCP. ${ }^{61} \mathrm{Hu}$ replaced Jiang as General Secretary at the $16^{\text {th }}$ Congress and as President a year later at the First Plenary Session of the $10^{\text {th }}$ National People's Congress in 2003. It was not until later that Jiang resigned from the office of Chairman of the CMC. This transition

57 Joseph Fewsmith, “Conclusion: China's Next Three Decades", in Joseph Fewsmith (ed.), China Today, China Tomorrow: Domestic Policies, Economy and Society (Lanham, Maryland: Rowman and Littlefield, 2010). 58 Datong Sun and Kaiqi Fang, “Weihu Dang he Guojia changuan liyi de genben baozheng- lun Deng Xiaoping zai xuanba jiebanren wenti shang de lishi gongxian" ["The Fundamental Guarantee to Safeguard the Long Term Interests of the Party and Nation- in Deng Xiaoping's historic contribution to the selection of his successor"], Jundui zhenggong yanjiu, [Theoretical Studies on PLA Political Works], No. 4, pp. 18-20.

59 Fewsmith, "The New Shape of Elite Politics", op. cit.

60 See James Mulvenon, "The Crucible of Tragedy: SARS, the Ming 361 Accident, Chinese Party-Army Relations", China Leadership Monitor No. 8, (Fall 2003) and James Mulvenon, "The Mystery of the Missing Godfather: Civil-Military Relations and the Shenzhou-5 Manned Space Mission", China Leadership Monitor No. 9, (Winter 2004). Two lines have similarly become apparent with $\mathrm{Hu}$ and $\mathrm{Xi}$, with the latter taking an active role in military affairs. "Xi Jinping yuanhe ling Meiguo 'jinzhang'” ["Why Xi Jinping makes America 'nervous'"], Duowei xinwen wang [DW Internet News], 25/08/2011.

61 An example of this recognition comes from a 1999 meeting between Jiang and Lee Kwan Yew, former Prime Minister and Minister Mentor of Singapore. In the course of their reported conversation, Jiang appeared to deliberately identify himself with Lee as a member of the "older generation of politicians", and that the older generation of leaders had a responsibility to "allow the new generation of leaders to arise as quickly as possible". The most telling part of the exchange is that Lee had initiated a leadership succession a few years before. "Jiang Zemin hujian Li Guangyao" ["Jiang Zemin meets Lee Kwan Yew"], Xinhua she [Xinhua News Agency], 27/09/99. 
was the most institutionalised in the history of the PRC, yet it was still not free of outside interference. Hu Jintao had been identified and elevated as a successor to Jiang by Deng. By selecting and elevating $\mathrm{Hu}$, Deng limited the struggle over the leadership after Jiang.

With no extra-institutional figure ${ }^{62}$ providing directions from behind the scenes today, how was Xi Jinping selected as the successor to Hu Jintao? This brings to light a significant question arising out of the two line leadership succession mechanism: namely, while it makes clear how the succession occurs, the mechanism does not define how the successors are selected. This is due to the self-imposed secrecy which envelops the CCP on most matters, particularly on leaders, leadership and succession. As Susan Shirk has written:

Understanding how Chinese politics work involves a lot of guesswork. To maintain their façade of unanimity, the Chinese Communist Party and the government keep their internal deliberations secret. ${ }^{63}$

Li Junru, Vice President of the CCP Central Party School has commented that the CCP has established a democratic mechanism to resolve the "problem of leaders picking successors". ${ }^{64} \mathrm{Li}$ argues that the process of selecting successors within the CCP has become a collective decision among the elite. ${ }^{65}$ Li's choice of words is telling. By referring to the "problem of leaders picking successors", Li's comments most likely reflect the conclusions reached by the Party in the years after the death of Deng. Li's comments elicit many questions regarding the nature of this democratic mechanism and frustratingly, the answers are not immediately clear. Yet a senior figure in the CCP has acknowledged that some semblance of a democratic process exists to facilitate the selection of the successors.

\section{Conclusion}

The two line leadership succession mechanism has been fully implemented once, under circumstances not free from interference. The transition leading into 2012 has so far conformed to the principles and procedures already established. Hu Jintao will undoubtedly step aside and Xi Jinping will assume the role of China's

62 Deng died in 1997, and no contemporary figure can match his political stature or influence.

63 Susan L. Shirk. China: Fragile Superpower. (New York: Oxford University Press, 2007). Frederick C. Teiwes concurs: "It is also necessary to reiterate the difficulty and tentativeness of the exercise. Simply put, to a very large extent current elite politics takes place in a black box, making key developments opaque to the outside observer and conclusions speculative. Nevertheless, some patterns are worth exploring". Frederick C. Teiwes. "Normal Politics with Chinese Characteristics". The China Journal No. 45 (Jan 2001).

64 "Zhonggong jiang minzhu jueding er buzai geren qinding jiebanren” [“Democratic Decision of the CCP: no longer personally chosen successor"], Zhongguo Pinglun Xinwenbao [China Review News], 22/03/2007.

65 Ibid. 
senior leader. Can the model survive the next transition, and the one after that? As transitions occur every decade, it is difficult to project its future success. The model provides some semblance of order to an otherwise incomprehensible process. The two line leadership succession mechanism raises some important points about the state of elite Chinese politics today.

While, like any political system, the political process in China is subject to the push and pull of individual figures and shifting personal allegiances, it is clear that institutions and processes play an increasingly important role. Political players are subjecting themselves to greater regulation, as they have concluded that stability and certainty are more important than complete freedom of action, which can culminate in instability and violence. With such processes at play in the elite, political institutionalisation at other levels is likely to be pursued. It is too early to speculate, but it is clear that if one crucial aspect of the process has been successfully institutionalised, other aspects surely will be into the future.

The implications are clear; greater institutionalisation in one part of the system (particularly at the top) will lead to institutionalisation in other parts. With some certainty on the question of leadership change, the world's most populous and, arguably most powerful authoritarian state has adapted its leadership processes to ensure a stable succession. The two line leadership succession mechanism is an evolving institution designed to enhance the security and development of the CCP and to assist the emergence of China as a world power in the twentyfirst century. 